https://doi.org/10.15407/scine16.02.042

\author{
BANNIKOV, D.O. and TIUTKIN, O.L. \\ Dnipro National University of Railway Transport \\ named after Academician V. Lazaryan \\ Lazaryan St., 2, Dnipro, 49010, Ukraine, \\ +380634004307, +38066290 4518, bdo2020@yahoo.com

\section{PROSPECTIVE DIRECTIONS OF THE DEVELOPMENT OF LOOSE MEDIUM MECHANICS}

Introduction. At present, in the field of loose medium mechanics there is a rather serious key problem, the absence of a universal theoretical concept for considering the behavior of the loose medium under different practical conditions. Such situation significantly impedes the further development of this industry, since theoretical models of bulk material, which now have been counted about 30, practically conflict with each other.

Problem Statement. In practice, such problem leads to numerous cases of failures of structures of various types, as a result of errors in determining the loads from the bulk material.

Purpose. Identification and formulation of the main directions of the further development of loose medium mechanics as a separate section of soil mechanics in the composition of geotechnical mechanics. The development of these directions is a solution for overcoming the problem of creating a unified theoretical model of loose medium.

Materials and Methods. The systematization and the synthesis of the accumulated information on loose medium mechanics and the development of a universal approach to describing its behavior is the main method to achieve the formulated purpose.

Results. Researching in three directions is the main prerequisite for the formation of the concept of loose medium. These directions are the determination of the properties of loose materials; the determination of the pressure ratio; and the development of a model for packing grains of loose material.

Conclusions. The discrete-continuum approach shall be basic concept for developing the unified theoretical model of loose medium. At the same time, all properties of loose medium are determined on the basis of its discrete nature; the equations of static equilibrium and the dynamic motion of the loose medium are formed considering it as a homogeneous continuum within a certain volume. Also, the static behavior of loose medium shall be analyzed as a partial case of its dynamic behavior rather than as an individual task with its own parameters.

Keywords: loose medium, bulk material, geotechnical mechanics, and discrete-continuum model.

Loose medium holds a special place among other types of environments studied by mechanics as a separate fundamental science. It is neither solid nor liquid (gas). That is why the characteristics of loose medium are studied as a separate direction of soil mechanics as part of geotechnical mechanics - loose material mechanics.

Citation: Bannikov, D.O. and Tiutkin, O.L. Prospective Directions of the Development of Loose Medium Mechanics. Sci. innov. 2020. V. 16, no. 2. P. 42-50. https://doi.org/10.15407/scine16.02.042 
The origin of this science is associated with researcher M. Bullet (the late $17^{\text {th }}$ century). Over the past 300 years, about several hundreds of thousands theoretical and experimental studies have been performed and laid the theoretical foundations of granular fluid mechanics. A list of the researchers contributing to this science is as long as to occupy, at least, an encyclopedic book. However, because of the characteristics of the bulk environment and the features of existing research methods, these numerous studies cannot have solved the key problems, so the results obtained and the predictive models contradict each other, both qualitatively and quantitatively.

Many modern researchers have recognized the fact that today there is no single physical model of loose medium, which, in turn, significantly complicates the design of various machines and structures for transportation, reload, and storage of bulk materials (conveyors, grooves, transporting systems, and bins/hoppers). In practice, this leads to numerous failures and accidents with such structures as, for example, silos for storage of agricultural products and grain or bins for storage and accumulation of ore agglomerates and coal (Figs. 1, 2). Moreover, according to statistics collected by the authors, about $50 \%$ of collapses and failures of the structures of this type are caused by errors in the calculation of loads from bulk materials.

The national standard DBN B.2.2-8-98 [1] that is, in fact, the identical translation of the previous standard SNiP 2.10.05-85 uses two theoretical models (by Charles Coulomb and by Hermann Jansen) to describe the static behavior of bulk material in capacitive structures. The first one is a hydrostatic model of the Newtonian fluid adapted to soils. It is used for designing low containers for bulk materials (bins, hoppers). The second one is Jansen's model improved by adjusting coefficients. It is used for designing high containers (silos).

The national standard DSTU-N B EN 1991-4: 2012 [2] that is a translated and adapted version of Eurocode EN 1991-4:2006 is based on Jansen's

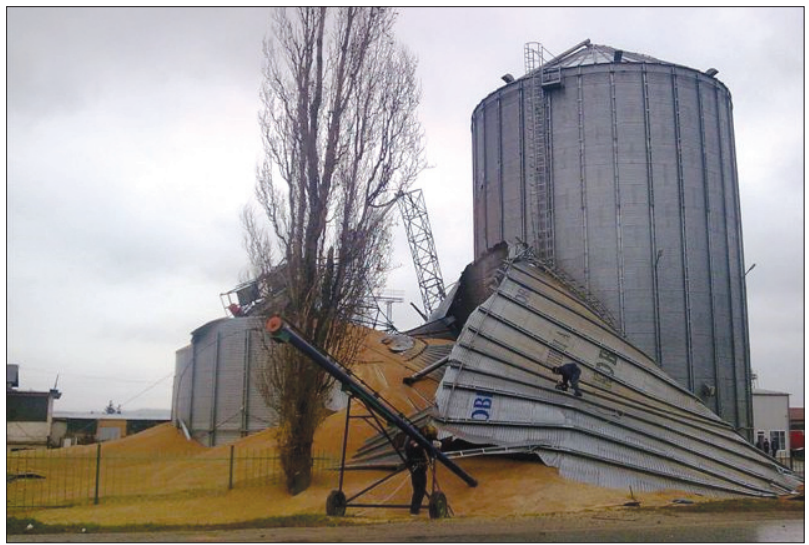

Fig. 1. Failure of steel grain storage facility

theoretical model adjusted with a system of special expressions, both for static local pressures in different parts of a closed capacitive structure and for dynamic processes of bulk material motion, depending on the structure design.

These standards have been compared in many modern researches (see, for example, [3]), from which it follows that the pressure of bulk material, according to European standards, is approximately twice higher than the similar pressure as determined in accordance with national standards, despite the fact that in the national standards there are special adjustment coefficients for the expressions, which for some parts of structures reach 2.0 .

The modern Ukrainian literature on loose media mechanics is mainly of a review character [4, 5 ] as it describes basic models for different types and cases of the use of bulk materials. Particularly interesting is the specialized professional literature [6-8] that actually summarizes almost all domestic experience in particular areas of production.

The modern foreign literature on loose media focuses mainly on the problems of proper simulation of bulk material and consideration of its properties, mostly, by means of existing computer methods $[9,10]$. The rest of the publications deals with description of the peculiarities of work of bulk materials in various conditions, often nonstandard ones [11]. The reference literature [12-14] that 

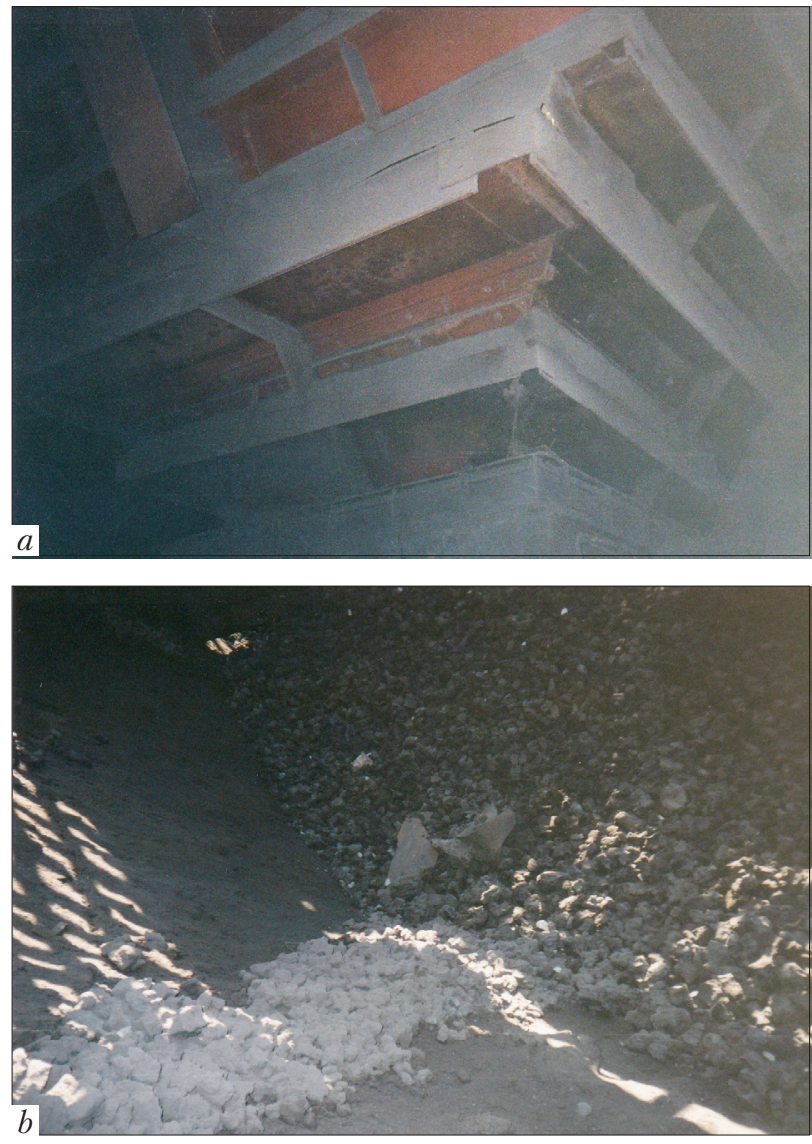

Fig. 2. Damage of steel hoppers for ore agglomerate storage: $a$ - broken reinforcement ribs; $b$ - destruction of brickwork

summarizes the foreign practical experience is also noteworthy.

Thus, the above review of bibliographic sources allows us to state that the main problem for today, as already noted, is a variety of developed and proposed theoretical models of loose medium. According to the authors' estimates, there are about 30 ones, however, only 5 of them, at most, have been officially recognized (that is included in the normative documents of different countries).

All available loose media models are grouped into the three main types: continuous, discrete, and discrete-continuous [15]. However, in practice, such a variety of models does not improve the situation and creates difficulties in the design of different types of structures, which leads to serious accidents during their operation [16].
A possible way out of this situation is to systematize and to summarize all the accumulated information on loose medium mechanics and to develop on this basis a single approach to describing bulk material behavior. The outlined problem can be solved gradually, based on the solution of smaller problems, each of which is limited by a number of factors that significantly hinder its solution. Therefore, the purpose of this research is to separate these problems that having been solved can contribute to creating a single theoretical model of loose medium and to identify the limitations in each case. Such separate problems are directions of research, and their analysis is accompanied with the corresponding authors' research and considerations.

In fact, the existing loose medium mechanics are a set of separate theoretical and practical problems. Each of them is relatively independent, considered and solved based on particular preconditions, and is based on particular theoretical ideas about the bulk material, with the use of particular theoretical models that often contradict each other.

The authors' classification of the main similar tasks is shown in Fig. 3. In the diagram, the horizontal rectangles show theoretical problems, and vertical ones represent practical solutions based on them. The lines connecting the rectangles mean the use of the corresponding solutions of other tasks.

Each such task can be divided into separate sub-tasks in terms of consideration / disregard of the symmetry, the shape of the bounding surfaces (if any), the grain composition of bulk material (e.g., fine-grained / coarse-grained).

Hence, loose medium mechanics can be conditionally divided into separate "mechanics" with their own axiomatic assumptions and relevant factors taken into account.

According to the authors, this approach is fundamentally and conceptually wrong. All separate scattered problems should be reduced to one theoretical model of loose medium and be only partial cases where certain parameters turn to zero 


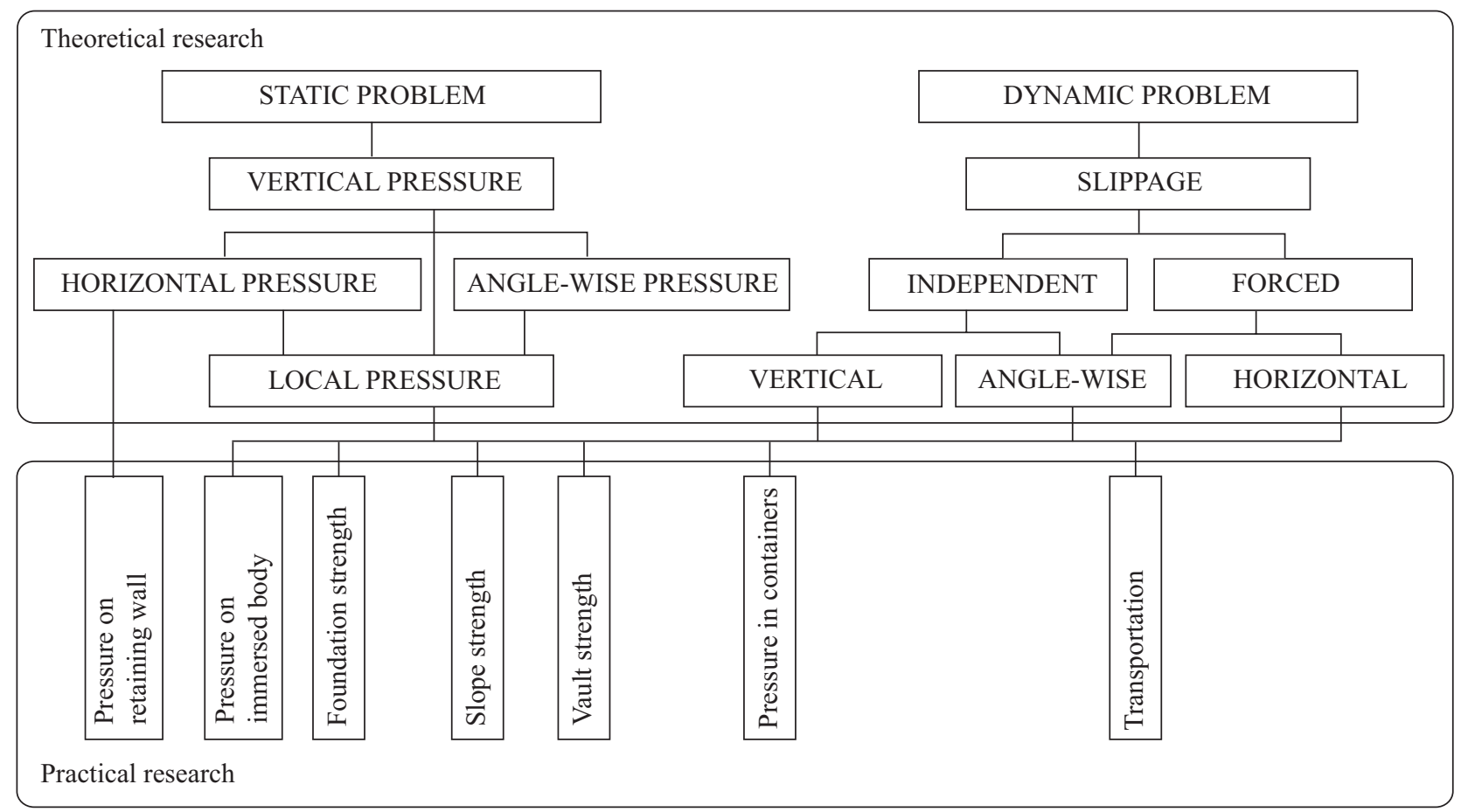

Fig. 3. Principal problems of loose medium mechanics

or infinity. The main directions that will contribute to the similar development of loose medium mechanics are as follows.

1. Determination of properties of bulk materials. A considerable attention has been given to this issue today. However, in many aspects it remains undisclosed and even substantially complicated.

The pioneer researchers of bulk matter, for example, Prof. I.P. Prokofiev (the $1^{\text {st }}$ half of the $20^{\text {th }}$ century) distinguished only three indicators: density, natural slope, and angle of internal friction as parameters for the description of the properties of bulk substance.

As of today, the situation is much more complicated. The national standards [1] take into consideration the five parameters: in addition to the above three, the angle of external friction on the container's material and the modulus of bulk substance deformation.

The foreign standards [2] describe the properties of bulk substance using the eight parameters. In addition to the above five characteristics, there are three more: specific gravity of suspended matter, Poisson's ratio, and adhesion coefficient.

Modern researchers, both Ukrainian [4,5] and foreign [9-11], have pointed out that these parameters are not enough and using them it is impossible to correctly describe the behavior of the bulk substance in the future and to build its theoretical model. This requires, at least, 20 different parameters, including those describing the grain size, such as the median diameter of the grain cluster and its equivalent variations: harmonic mean diameter, median Laschinger diameter, median Muller diameter, median Andreazen diameter, median shape diameter, and median mix diameter. Also, the structure of bulk material is described by numerous parameters: the grain stacking angle, bulking angle, sliding angle, porosity, pore volume, the coefficient of staking density.

In addition, for each parameter, there are different, as a rule, the latest methods of its quantification. However, often it is enough if some parameters of loose medium are already known (for 
example, density or angle of internal friction), and others are determined on their basis. This means they are not fully independent and, accordingly, errors in determining the first parameters distort the values of derivative ones.

Moreover, even methods for measuring the "classical" parameters of a bulk substance, such as density, differ from one another. For example, bulk density can be measured in five different ways: fluidized bed weighing, hydrostatic weighing, gas pycnometry, physical pendulum method, and sectional rotor method.

Particularly noteworthy is adhesion between individual grains. Quite often, its concept is misinterpreted, which leads to the development of completely unrealistic models.

Many experts believe that bulk material in its classical sense has no adhesion between individual grains, there are only compression and friction forces. However, due to a physical impact (such as crimping) or an increase in the fluid content of the material (for example, as a result of natural absorption from the atmosphere), bonds that produce tensile forces arise between the individual grains. Under a certain load, such bonds are broken and the grains are separated from one another. Such processes take place in soils, such as clays. However, the regularities built for this case often can be applied for other types of materials, for example, for crushed rock soils that, even being wet, have such a low adhesion that it can be neglected.

That is why the loose medium mechanics shall clearly distinguish the two categories of substances: with adhesion and without adhesion. According to the authors, the term "bulk material" can be used in the second case.

In the authors' opinion, such a diversity of parameters of loose medium is explained by the grain structure of loose medium that consists of individual particles of various (in fact, arbitrary) geometric size and shape, as a result of which there are formed voids between the particles. The authors propose to use fractal geometry methods to describe such a structure mathematically. Of course, this leads to some mathematical difficulties, but makes it possible to present all the structural peculiarities of material in an analytical form, thus reducing the number of their parameters. One of the possible fractals for this case can be the adapted Chebyshev fractal for a 3D problem.

On the other hand, the analytical representation of the bulk material structure makes it possible to proceed to its modeling with the help of one of the numerical methods of construction mechanics, namely, the finite element method. However, because of the averaged characteristics of loose medium, the parameters of a special finite element should be set with the help of analytical fractal expressions, instead of doing this in the conventional way. Currently, the authors have been carrying out research in this field.

2. Determination of pressure ratio. This issue is one of the basic for the further construction of any theoretical model of bulk material. Usually, researchers consider lateral pressure coefficient $K$. Its key role in many models of bulk material is to link the vertical pressure in material at a certain depth with the horizontal pressure.

For liquids, this coefficient is equal to 1 , which means that pressure is uniform in all directions. For bulk materials, this coefficient is given in standards [1,2] and is less than 1 , which means the transfer of pressure with a decrease in it. However, some authors point out that the lateral pressure factor may be greater than 1 (!), although they attribute this case to soils that have been pre-compacted (for example, by an ice layer in an ice period). For loose, especially in-bulk, materials, no such data have been available.

Thus, for bulk matter, the problem of determination of the lateral pressure coefficient remains open. In all officially recognized models of bulk matter [1,2], the lateral pressure coefficient is determined by V. Rankine's expression obtained for equilibrium bulk wedge in an unbounded body.

Subsequently, other expressions were proposed to determine the mentioned coefficient, the most well-known of which are given in Table. 1 . This Table also shows the quantitative values of this 
coefficient, depending on the basic parameter describing the physical and mechanical properties of bulk substance, the angle of internal friction $\psi$.

It should be noted that all above expressions were obtained when considering the bulk material as a continuous body, i.e. without taking into account the geometry and structure of the bulk substance, as well as the interaction of the bulk material with the elements of the surface on which its pressure is determined. In particular, the friction of grains on the wall or the formation of the so-called surface layer of several grains along the surface, as established by the authors in the experimental studies, is neglected. The specified layer has a specific structure that differs from the structure of the bulk material and slightly depends on the angle of inclination of the contact surface (Fig. 4).

A separate aspect of the considered research direction is the determination of lateral pressure coefficient for the surface inclined at an arbitrary angle to the vertical. In this case, the coefficient name is no longer correct and shall be changed for the pressure ratio.

Prof. I.P. Prokofiev tried to solve this problem in the early 20th century. He obtained a solution for the state of limit equilibrium of the bulk material, from which it followed that the lateral pressure coefficient grew as deviation of the pressure surface from the vertical increased.

Modern Ukrainian researchers [1] do not consider this issue assuming that the transfer of pressure to the inclined surface in the bulk material is

\section{Table 1. Lateral Friction Coefficient of Bulk Material}

\begin{tabular}{|l|c|c|c|c|}
\hline \multirow{2}{*}{\multicolumn{1}{c|}{ Author }} & \multirow{2}{*}{ Formula } & \multicolumn{3}{c|}{$K$ at $\psi$} \\
\cline { 3 - 5 } & & $15^{\circ}$ & $25^{\circ}$ & $35^{\circ}$ \\
\hline V. Rankine & $K=\frac{1-\sin \psi}{1+\sin \psi}$ & 0.59 & 0.41 & 0.27 \\
M. Jacky & $K=1-\sin \psi$ & 0.74 & 0.58 & 0.43 \\
J. Biarez & $K=\frac{1-\sin \psi}{\cos \psi}$ & 0.77 & 0.64 & 0.52 \\
G.I. Pokrovski & $K=1-0,74 \tan \psi$ & 0.80 & 0.66 & 0.48 \\
L.V. Giachev & $K=\frac{1,5}{2-1,75 \tan \psi}$ & 0.61 & 0.53 & 0.47 \\
\hline
\end{tabular}

ISSN 2409-9066. Sci. innov. 2020. 16 (2)
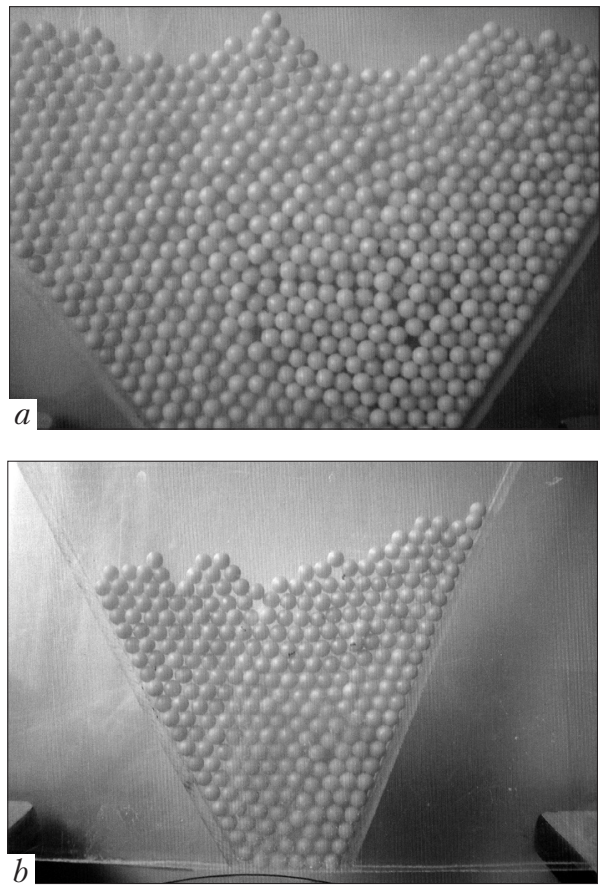

Fig. 4. Surface layer of bulk material at an inclination angle of lateral surface of $50^{\circ}(a)$ and $65^{\circ}(b)$

similar to that in a solid. Foreign experts [2] practice a similar approach using a special adjustment coefficient determined mainly by results of experimental studies.

3. Development of a grain stacking model. The next basic aspect of bulk material research is the development of a grain stacking model that would be as reliable and experimentally confirmed as possible.

Among the assumptions to be taken into account while developing this model there are as follows:

- individual grains try to occupy the lowest possible position under the action of gravity force;

- the densest stacking takes place where the distances between the centers of adjacent grains are the shortest;

- during the movement of bulk material, the above assumptions are maintained.

These factors have been considered in the course of theoretical and experimental studies and are detailed in monograph [15]. However, the grain model of bulk material used there is quite simple. 


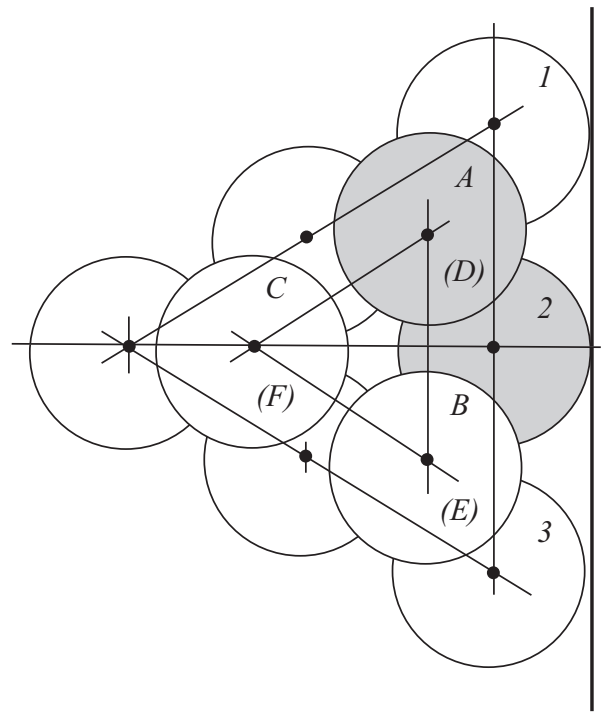

Fig. 5. Uniform stacking of grains of loose medium: $A-C-$ the upper layer grains; $D-F-$ bottom layer grains; $1-3-$ lateral grains

It is assumed that grains of the same geometric shape are stacked in geometrically equal rows of three layers (Fig. 5), which is obviously a simplification. The upper row is formed by grains $A, B$, and $C$, the lower row consists of grains $D, E$, and $F$. The intermediate layer (the extreme grains are indicated by numbers) is located between the above mentioned layers, so that the grains of the extreme layers occupy the lowest possible position.

If the bulk material exerts a certain pressure a flat wall, the model is relatively clear. In the case of a curved wall the problem gets significantly complicated. In fact, no data on the bulk material grain distribution for the surfaces of various geometric shapes have been available. However, in recent years, capacitive structures with various corrugated walls have been used quite often. Obviously, the conventional models in this case are invalid and we need conducting special studies such as those described by the author in [17].

Traditionally, in the theory of bulk material, static and dynamic behavior of bulk material is considered as two different problems. Some authors explain this approach by the complexity of the processes of bulk material flow and "unpredictability" of this phenomenon.
Meanwhile, mechanics, as a fundamental science, considers the absence of motion of any object. This means a static problem is only a partial case of a dynamic problem. The "unpredictability" of a bulk substance is reduced to a number of specific dynamic effects, such as local high pressure or pulsations.

According to the authors, the prerequisites for such a situation are the lack of certainty regarding the three previous problems (directions) discussed above. This leads to the absence of a single theoretical approach to describing the behavior of loose medium, and even the general concept of such an approach is rather vague and inconsistent.

Out of all the existing and presented concepts, the most universal is the discrete-continuous approach. In this case, all properties of loose medium are determined based on its discrete nature on the basis of experimentally determined stacking patterns for various practical cases. Proceeding from this, the lateral pressure coefficient (possibly, several values for different practical cases) can be determined using a mathematical apparatus. The static equilibrium equation and the equation of dynamic motion of loose medium are formed assuming that it is a homogeneous continuous medium within a certain volume.

This approach may result in obtaining more than one practical solution for different initial conditions, as shown in [15].

Analyzing all above mentioned considerations it is possible to summarize the main directions of modern development of loose medium mechanics and further research.

1. At present, there is no unified approach to the development of a theoretical model of loose medium. All available models are contradictory, single-purpose and do not correspond to experimental data and practical situations.

2. The basic concept for developing a theoretical model of loose medium should be the discretecontinuous approach. In this case, all properties of loose medium are determined on the basis of its discrete nature, and equations of static equi- 
librium and dynamic motion are written assuming that the loose material is a homogeneous continuous medium within a certain volume.

3. The loose medium concept shall be based on research in the three directions:

- determination of the properties of bulk materials;

- determination of the pressure ratio; and

- development of a grain stacking model.

4. Proceeding from the conceptual solution of these three problems, further opportunities will arise for a more detailed study of individual partial problems as well as physical and mechanical processes in loose medium. Such problems include, first of all, dilatancy, contractancy, strain localization bands, segregation, stratification, clusterization, cave formation, surface layer formation, filtration leakage of bulk material from openings, and the like.

\section{REFERENCES}

1. DBN B.2.2-8-98. (1998) Enterprises, buildings and structures for storage and processing of grain. Kiev, Ukraine. 41 p. [in Ukrainian].

2. DSTU-N B EN 1991-4:2012. (2012). Eurocode 1. Actions on structures. Part 4. Bins and tanks. Kiev, Ukraine. 168 p. [in Ukrainian].

3. Bibik, M. V., Moroz, P. S. (2014). Determination of horizontal load on the vertical walls of capacitive structures according to different norms. Collection of scientific works of PoltNTU (branch machine-building, construction), 1(40), 166-174 [in Ukrainian].

4. Ljaptsev, S., Afanasjev, A., Tsirkova, A. (2014). Resonant vibration transport machines for bulk materials. LAP Lambert Academic Publishing [in Russian].

5. Voblikov, E. M. (2010). Technology of elevator industry. Lan [in Russian].

6. Vinokurov, K. V., Nikonorov, S. N. (2008). Elevators, warehouses, grain dryers. Saratov State Technical University [in Russian].

7. Gorjushinsky, I. V., Kononov, I. I., Denisov, V. V., Gorjushinskaja, E. V., Petrushkin, N. V. (2003). Capacities for bulk cargo in transport and cargo systems. SamGAPS [in Russian].

8. Semenov, V. Ph. (1999). Bins and grain storages. Alatai State Techical University [in Russian].

9. Handbook of Granular Materials. (2015). In S. V. Franklin, M. D. Shattuck (Eds.). CRC Press, 522. doi.org/10.1201/ b19291.

10. Granular Materials. (2017). In M. Sakellariou Ed.). InTech. doi.org/10.5772/66007.

11. Cambou, B., Magoaeriec, H., Nguyen, N-S. (2016). Granular Materials at Meso-Scale. Elsevier LTD, 164. doi.org/10.1016/ c2015-0-01312-0.

12. ESDEP WG: Vol. 15: Structural Systems. Bins: Lecture 15C.2, 34

13. Structural Engineering Handbook. (1997). In Edwin H. Gaylord, Jr., Charles N. Gaylord, James E. Stallmeyer (Ed.). McGraw-Hill.

14. Fruchtbaum, Ja. (1988). Bulk Materials Handling Handbook. SpingerLink. doi.org/10.1007/978-1-4757-4695-2.

15. Bannikov, D. O. (2009). Bulk material in capacity structure. Dnipropetrovsk [in Ukrainian].

16. Kachurenko, V. V., Bannikov, D. O. (2016). Structural solutions for steel capacities for granular materials. Dnipropetrovsk [in Russian].

17. Kachurenko, V. V., Bannikov, D. O. (2014). Features of simulation of granular material pressure on corrugated steel elements. Collection of scientific works "Resource-saving materials, constructions, buildings and structures", 28, 367-376 [in Ukrainian].

Received 11.12.18

Revised 04.04.19

Accepted 07.05.19 
Д.О. Банніков, О.Л. Тотькін

Дніпровський національний університет

залізничного транспорту імені академіка В. Лазаряна,

вул. Лазаряна, 2, Дніпро, 49010, Україна,

+380 63400 4307, +380 66290 4518, bdo2020@yahoo.com

\section{ПЕРСПЕКТИВНІ НАПРЯМИ РОЗВИТКУ \\ МЕХАНІКИ СИПУЧОГО СЕРЕДОВИЩА}

Вступ. На сьогодні в галузі механіки сипучого середовища існує серйозна ключова проблема, яка полягає у відсутності єдиної теоретичної концепції розгляду поведінки сипучого середовища в різних практичних умовах. Це суттєво гальмує подальший розвиток зазначеної галузі, адже окремі теоретичні моделі сипучого матеріалу, яких налічується біля 30, практично не узгоджені між собою.

Проблематика. На практиці окреслена проблема призводить до численних випадків відмов та аварій будівельних конструкцій різних типів, що є наслідком помилок при визначенні навантажень від сипучої речовини.

Мета. Визначення та формулювання основних сучасних напрямів подальшого розвитку механіки сипучого середовища, як окремого розділу механіки грунтів у складі геотехнічної механіки. Розробка цих напрямів є рішенням до подолання проблеми створення єдиної теоретичної моделі сипучої речовини.

Матеріали й методи. Систематизація та узагальнення накопиченого масиву інформації щодо механіки сипучого середовища та розробка на основі цього єдиного підходу до опису його поведінки є основним методом досягнення сформульованої мети.

Результати. Основними передумовами формування концепції сипучого середовища є проведення досліджень в трьох напрямках: визначення властивостей сипучих матеріалів; визначення коефіцієнту передачі тиску; побудова моделі укладки.

Висновки. Базовою концепцією побудови єдиної теоретичної моделі сипучого середовища повинен бути дискретно-континуальний підхід. При цьому всі властивості сипучого середовища визначаються, виходячи з його дискретної природи, а рівняння статичної рівноваги та динамічного руху сипучого середовища формуються, розглядаючи його як однорідне континуальне середовище в межах певного об'єму. Також статична поведінка сипучого середовища має аналізуватися як частковий випадок його динамічної поведінки, а не як окрема самостійна задача зі своїми власними параметрами.

Ключові слова: сипуче середовище, сипучий матеріал, геотехнічна механіка, дискретно-континуальна модель. 